\title{
In Which Journals Do Active Researchers of Palliative Care Publish Their Articles?
}

\author{
Maria Teresa San-Miguel, R.N., Carlos Centeno, M.D., Ph.D., Ana Carvajal, R.N., Ph.D., ${ }^{1}$ and Mariano Ponz, M.D. ${ }^{3}$
}

Dear Editor:

The final question that a researcher asks once his or her work is completed is "which journal should I send this article to?" It is recommended that researchers publish their articles in one of the 3,700 leading world scientific journals that are included in the Science Citation Index (SCI); the highest impact factor (IF) is specified according to the Journal of Citation Report, with the higher position specified within its subcategory, Journal. There are criticisms relating to the equity, opportunity, and interest of measure ${ }^{1}$ research within these criteria, but evaluation agencies constantly seek to obtain this quality indicator in order to compare curricula for professional promotion or in the competition for grants. Ultimately, researchers, like any other human beings, must make an income from their work, and the prestige emanating from these classifications may be important in enabling them to achieve that. Our research question could therefore be of relevance to many professional groups.

The objective of this work is to identify in the journals in which the most active palliative care researchers have published their works in the last three years. In order to find out who these active researchers are, we selected the authors that contributed in excess of six abstracts to one or both of the European Association of Palliative Care Research Congresses, which took place in Venetia ${ }^{2}$ and Trondheim ${ }^{3}$ (2006 and 2008, respectively). Then, we searched the SCI in order to obtain references from the work of these researchers between 2007 and 2009. From the SCI references, we ranked the journals by frequency, noting both the 2008 IF and the best quartile position within the category of each journal.

We found the 28 most active researchers in the last two European Research Congresses. These authors contributed 516 references in 119 different SCI journals during the last three years (Table 1). In Table 2 we demonstrate the distribution by journal: 232 of the articles ( $45 \%$ ) belong to five main journals of the Health Care Science and Service category: Palliative Medicine (18\%), Journal of Palliative Care (13\%), Journal of Pain and Symptom Management (12\%), Journal of Palliative Medicine (7\%), and Supportive Care in Cancer (5\%). It is also important to emphasize the contribution of palliative care researchers to journals classified within the category of Oncology: 72 articles (14\%) were published in journals included in this category. Other categories where in excess of three articles were published include anesthesia, health care science, general medicine, neurology, nursing, pharmacology, psychology and public environmental and occupational

Table 1. Number of Articles Published by Most Active Researchers in Science Citation Index JOURNALS BETWEEN 2007 AND 2009

\begin{tabular}{|c|c|c|c|}
\hline \multirow[b]{2}{*}{ Researcher } & \multirow{2}{*}{$\begin{array}{c}\text { Contributions in } \\
\text { last two European } \\
\text { Research Conferences }\end{array}$} & \multicolumn{2}{|c|}{$\begin{array}{l}\text { Articles in Journal } \\
\text { of Science Citation } \\
\text { Index, 2007-2009 }\end{array}$} \\
\hline & & $\mathrm{n}$ & $\%$ \\
\hline Stein Kaasa & 32 & 38 & 7 \\
\hline Luc Deliens & 29 & 45 & 9 \\
\hline Lucas Radbruch & 21 & 24 & 5 \\
\hline Declan Walsh & 18 & 15 & 3 \\
\hline Jon Havard Loge & 17 & 19 & 4 \\
\hline Sheyla Payne & 17 & 14 & 3 \\
\hline Julia Addington-Hall & 16 & 20 & 4 \\
\hline David Currow & 14 & 34 & 7 \\
\hline Gerrit Van der Wal & 13 & 32 & 6 \\
\hline Mellar Davis & 12 & 12 & 2 \\
\hline Friedemann Nauck & 12 & 10 & 2 \\
\hline Robin Fainsinger & 11 & 21 & 4 \\
\hline Scott Murray & 11 & 12 & 2 \\
\hline Marie Fallon & 10 & 16 & 3 \\
\hline Sophie Pautex & 10 & 10 & 2 \\
\hline Florian Strasser & 10 & 17 & 3 \\
\hline Eduardo Bruera & 9 & 59 & 11 \\
\hline Carlos Centeno & 9 & 10 & 2 \\
\hline David Clark & 9 & 11 & 2 \\
\hline Franco De Conno & 9 & 6 & 1 \\
\hline Amy Abernethy & 8 & 2 & 0 \\
\hline Richard Harding & 8 & 18 & 3 \\
\hline Lesley Colvin & 7 & 9 & 2 \\
\hline Irene Higginson & 7 & 43 & 8 \\
\hline Javier Rocafort & 7 & 3 & 1 \\
\hline Claudia Mazzocato & 6 & 2 & 1 \\
\hline Carla Ripamonti & 6 & 9 & 2 \\
\hline Carla Stiles & 6 & 5 & 0 \\
\hline Total & 344 & 516 & 100 \\
\hline
\end{tabular}

${ }^{1}$ Palliative Care and Symptom Control Unit, University of Navarra Clinic, Pamplona (Navarra), Spain.

${ }^{2}$ School of Nursing, University of Navarra, Pamplona (Navarra), Spain.

${ }^{3}$ Oncology Department, University of Navarra Clinic, Pamplona (Navarra), Spain. 
Table 2. Journals Where Researchers of Palliative Care Publish Their Works

\begin{tabular}{|c|c|c|c|c|}
\hline Journal of Science Citation Index & Category in journal citation report & $\begin{array}{l}2008 \text { impact } \\
\text { factor }\end{array}$ & $\begin{array}{l}\text { Position (quartile) } \\
\text { in category }\end{array}$ & $\begin{array}{c}\text { Articles } \\
\text { 2007-2009 N (\%) }\end{array}$ \\
\hline Pallliative Medicine & Health care science \& service & 1,874 & Q2 & $94(18)$ \\
\hline Journal of Palliative Care & Health care science \& service & 0,985 & $\hat{\mathrm{Q}} 4$ & $15(3)$ \\
\hline $\begin{array}{l}\text { Journal of Pain and Symptom } \\
\text { Management }\end{array}$ & Health care science \& service & 2,601 & Q1 & $62(12)$ \\
\hline Journal of Palliative Medicine & Health care science \& service & 1,909 & Q2 & $35(7)$ \\
\hline Supportive Care in Cancer & Health care science \& service & 2,422 & Q1 & $26(5)$ \\
\hline Journal of Clinical Oncology & Oncology & 17,157 & Q1 & $17(3)$ \\
\hline Psycho-Oncology & Oncology & 3,150 & Q2 & $3(1)$ \\
\hline European Journal of Cancer & Oncology & 4,475 & Q2 & $12(2)$ \\
\hline Annals of Oncology & Oncology & 4,935 & Q1 & $8(2)$ \\
\hline OTHER Journal of Oncology & Oncology & - & - & $35(7)$ \\
\hline OTHER JOURNALS & & & & $209(41)$ \\
\hline
\end{tabular}

health. Looking at IF, a significant number of papers were published in many of the leading journals in the field: for example, 17 articles were published in Journal of Clinical Oncology with IF 17,157.

In summary, five journals were the main target of the palliative care researchers (these journals had an IF less than three; however, two of them were in the first quartile of the category). These journals reflected the largest contribution of palliative care research ${ }^{4}$ and it is worth noting that the best palliative care researchers chose these journals for the diffusion of new knowledge. Furthermore, one half of the journal articles were disseminated in a huge number of journals (especially oncology ones) and this may be a further area of opportunity for publication by other palliative care researchers. Finally, the specialties of geriatrics and internal medicine are at the bottom of the categories; it can therefore be assumed that palliative care research may be closely aligned with the specialty of oncology.

\section{Author Disclosure Statement}

This research received no specific grant from any funding agency in the public, commercial, or not-for-profit sectors.

\section{References}

1. Ha TC, Tan SB, Soo KC. The journal impact factor: too much of an impact? Ann Acad Med Singapore 2006; 35:911-916.

2. Abstracts of the 4th Research Forum of the European Association for Palliative Care (EAPC), Venice, Italy, May 25-27, 2006. Palliat Med 2006; 20:129-279.

3. Abstracts of the 5th Research Forum of the European Association for Palliative Care (EAPC), Trondheim, Norway, May 28-31, 2008. Palliat Med 2008;22:399-558.

4. Elsner F, Centeno C, De Conno F, Ellershaw J, Eychmuller S, Filbet M, Kaasa S, Larkin P. Recommendations of the European Association for Palliative Care for the development of postgraduate curricula leading to certification in Palliative Medicine. Report of the EAPC Task Force on Medical Education. EAPC, Milan 2007. www.eapcnet.org/download/for Taskforces/PhysiciansTF/EAPC-CurrPostgraduateMedEdu .pdf. (Last accessed on March 2010.)

Address correspondence to: Carlos Centeno, M.D., Ph.D. Palliative Care and Symptom Control Unit University of Navarra Clinic Avenida Pio XII 37 31008-Pamplona (Navarra), Spain E-mail: ccenteno@unav.es 